DOI https://doi.org/10.33766/2524-0323.86.157-170 УДК 343.3/.7

\section{С. А. Шалгунова,}

кандидат юридичних наук, доцент, завідувач кафедри кримінально-правових дисциплін

Дніпропетровського державного університету внутрішніх справ

(м. Дніпро, Україна)

e-mail: mail@dduvs.in.ua

(iD https://orcid.org/0000-0001-6816-6056

А. С. Скок,

кандидат юридичних наук, доцент кафедри

кримінально-правових дисциплін

Дніпропетровського державного

університету внутрішніх справ

(м. Дніпро, Україна)

e-mail: mail@dduvs.in.ua

(iDhttps://orcid.org/0000-0002-0981-6415

\title{
ФОРМУВАННЯ АНТИНАРКОТИЧНОГО ЗАКОНОДАВСТВА УКРАЇНИ ІЗ ВРАХУВАННЯМ ДОСВІДУ СВРОПЕЙСЬКИХ КРАЇН У СФЕРІ БОРОТЬБИ 3 НАРКОЗЛОЧИННІСТЮ
}

Стаття присвячена процесам формування антинаркотичного законодавства України з урахуванням досвіду європейських країн у сфері боротьби $з$ наркозлочинністю. У статті вивчено міжнародні документи, які визначають принципи, методи та основні напрямки державної антинаркотичної політики. Розглянуто кримінальне законодавство щодо особливостей встановлення кримінальної відповідальності за наркотичні злочини. Виявлено проблеми підміни понять у вітчизняному кримінальному законодавстві та встановлено, що національна антинаркотична політика грунтується на міжнародних правових актах, прийнятих переважно ООН.

Ключові слова: наркотики, наркоманія, наркобізнес, наркозлочинність, кримінальна відповідальність, антинаркотична політика.

Постановка проблеми. Вітчизняні правові норми, що регламентують питання законного обігу психотропних речовин, грунтуються на міжнародних положеннях нормативно-правових актів 3 питань регулювання їх обігу. Регламентація порядку обігу психотропних речовин стала логічним продовженням регламентації наркотичних засобів. І тому, для того щоб вирішити, які правові норми прийняті для регламентації, необхідно визначити, яким чином формувалося міжнародне законодавство в цій сфері. Незважаючи на велику увагу до проблем наркозлочинності в Україні та світі, залишається ряд невирішених проблем. Так питанням розгляду розвитку міжнародного законодавства та появи в ньому правових (C) Шалгунова С. А., Скок О. С., 2019 
заборон для вільного обігу психотропних речовин, що прирівняні до наркотичних засобів, увага не присвячувалася.

Аналіз останніх досліджень і публікацій. Низка учених, як-от: Ю. В. Александров, А. В. Андрушко, Ю. В. Баулін, В. І. Борисов, О. М. Джужа, В. В. Голіна, В. П. Ємельянов, А. А. Музика, Е. В. Расюк, Р. М. Павленко, І. О. Топольскова, І. І. Митрофанов, С. В. Нікітенко, I . В. Однолько, Р. М. Павленко, Ю. Г. Пономаренко, В. Г. Пшеничний, М. П. Селіванов, В. М. См ітієнко, В. А. Тимошенко, І. К. Туркевич, а також І. О. Топольскова, Є. В. Фесенко, В. І. Шакун, О. В. Юношев, О. С. Яценко, - досліджували проблеми, пов' язані із наркозлочинністю.

Формування цілей. Метою статті є аналіз чинного законодавства України та міжнародних нормативно-правових актів у сфері боротьби із проявами наркозлочинності, а також їх вплив на державну антинаркотичну політику.

Виклад основного матеріалу. Історичний розвиток свідчить про наявність різних видів наркоманій з давніх часів у суспільному житті. Можна говорити про те, що практично нічого не змінилося у вживанні наркотиків: людина, як i сотні років тому, прагне отримати задоволення, впасти в дурманний сон. Як вказує I. М. Симакова, перше знайомство людини з наркотиками відбулося ще десять тисяч років до нашої ери. Європейські країни познайомилися 3 наркотиками приблизно п'ять тисяч років тому. Їх, на думку Гіппократа, до Європи завезли скіфи $[1,2]$. Разом із тим до середини XIX ст. поширеність немедичного вживання наркотичних засобів була відносно невеликою та викликана переважно національними й історичними традиціями. Однак, ми вважаємо, що мешканці європейських країн набагато раніше стали споживати наркотичні засоби рослинного походження. Така думка пов'язана із тим, що Давньоримська імперія, яка була частиною Європи, охоплювала на момент свого існування не лише сучасну територію Італії, а й землі інших сучасних європейських країн. А в ній 3 давніх часів вживання одурманюючих речовин, особливо для знаті, заможних громадян, вважалося цілком прийнятним. У східних країнах (Китаї, Японії, Індії, Туреччині) та в Єгипті вживання наркотиків було цілком нормальним та прийнятним для більшості населення, а для духовних осіб (старійшин, шаманів, жерців) обов'язковим при проведенні обрядів та входженні в транс. 3 середини XIX ст. наркотики рослинного походження із Індокитаю та Південно-Східної Азії, як місць ïх традиційного вживання, почали переміщуватися до країн Західної Європи та Америки. У XIX-XX ст. немедичне застосування та вживання наркотиків стало 3 цього часу серйозною проблемою суспільства для багатьох держав, що викликало законодавче обмеження їх поширення.

Першим документом у сфері протидії наркозлочинам можна назвати Шанхайську опіумну комісію, створену в 1909 році [3]. Головним ії призначенням стало встановлення міжнародного контролю за наркотичними засобами в країнах, які до неї приєдналися та 
розробка заходів боротьби 3 немедичним їх вживанням на міжнародному рівні. Зібрання вказаної комісії стало офіційним початком міжнародно-правової боротьби з поширенням наркотиків у світі та їх немедичним вживанням. Делегати, які стали учасниками даної комісії, не приймали міжнародних чи дипломатичних актів, оскільки не мали таких повноважень. Прийняті комісією документи не містили жодних заборон, але в цілому робота, проведена Шанхайською комісією, мала велике значення.

Перша Конвенція про наркотики була прийнята в 1912 році (м. Гаага, Міжнародна конференція щодо опіуму, 1.12.191123.01.1912 р.р.) [4]. Вона стала першим міжнародно-правовим актом, у якому були визначені конкретні види наркотиків, обіг та вживання яких було поставлено під міжнародний контроль. Кожна країна, яка стала учасником даної міжнародної конференції, була згодна прийняти на себе певні зобов'язання. Зміст їх полягав у прийнятті національних законів, якими обмежувався обіг наркотиків, їх вироблення, поширення опіуму-сирцю, перешкоджання його незаконному ввезенню-вивезенню в країну (ст. 1), запровадження необхідності отримання дозволів на переміщення наркотиків в межах країни, створення уповноважених державних структур на видачу дозволів для обігу наркотиків, заходи по обмеженню й подальшій ліквідації неконтрольованого виробництва наркотиків, обмеження та подальша заборона торгівлі в межах країни опіуму для паління, заборона його ввезення та вивезення з країни (ст.ст.6,7), встановлення обмежень у використанні наркотиків та наркотичних засобів з немедичними цілями, законодавче закріплення можливості вільного, але контрольованого використання наркотичних засобів лише в медицині та фармакології (ст.ст. 9, 10, 11, 12, 13), запровадження чіткого законодавчо врегульованого механізму виробництва наркотичних засобів (морфіну, медичного опіуму, героїну, кокаїну та їx похідних), врегулювання порядку та правил торгівлі медичними наркотичними засобами та наркомісткими препаратами, аналіз чинного антинаркотичного законодавства, у тому числі кримінально-правових заборон, пов'язаних із незаконним зберіганням обігу наркотиків (ст. 20) [4].

Таким чином, положення про необхідність правового регулювання наркотиків, і зокрема, морфіну та його похідних, стало досить важливим кроком в обмеженні вільного обігу наркотиків. Такий акт став першим в обмеженні неконтрольованого виробництва, продажу, зберігання морфіну як найбільш полишеного виду наркотичних засобів.

За часів Першої світової війни та в післявоєнний період ситуація 3 незаконним обігом наркотиків та наркоманією у світі загострилася і до 20- х років набула загрозливих масштабів. Тому новим кроком в обмеженні обігу наркотиків у світі стало проведення другої Женевської конференції 1925 року. Прийнята на цій конференції Конвенція щодо опіуму 1925 року [5] стала тим правовим актом, у якому міжнародна спільнота визначила можливість суто законного вироблення наркотиків для потреб кожної держави 
(медичних, фармакологічних, наукових).

Наступним міжнародно-правовим актом у системі законодавчих документів, спрямованих на боротьбу із незаконним обігом наркотиків та наркоманією, стала Конвенція про обмеження виробництва та регламентації змісту розподілу наркотичних засобів 1931 року (м. Женева) [5]. Даною конвенцією було затверджено перелік наркотиків, що заборонялися для вільного обігу, і які, відповідно, повинні були мати спеціальний режим обігу.

Для заповнення прогалин в антинаркотичному законодавстві було прийнято у 1936 році нову конвенцію, що стосувалася безпосередньо проблем боротьби з нелегальним обігом сильнодіючих речовин [6].

Упродовж Другої світової війни, як і протягом їі, на міжнародному рівні нових законодавчих актів з питань незаконного обігу наркотиків та психотропів не приймалося. Лише після iї закінчення та часткового відновлення нормального мирного життя, з появою нових наркотичних засобів та психотропних речовин не лише рослинного, а й синтетичного характеру у 1948 році на міжнародному рівні було підписано Протокол про поширення міжнародного контролю щодо наркомістких лікарських засобів [7].

Після цього ООН, як міжнародна організація, створена з метою спільного розв'язання проблем як міжнародного, так і світового масштабу, прийняла на себе функції прийняття міжнародно-правових актів у сфері боротьби 3 незаконним обігом наркотичних засобів та психотропних речовин, немедичне споживання яких стали набувати загрозливого масштабу для населення різних країн світу. Так у 1961 році ООН було прийнято Єдину конвенцію про наркотичні засоби (м. Нью-Йорк), до якої Україна, яка на той час перебувала в складі СРСР, приєдналася в 1964 році. У ній так само, як і в попередніх, була закріплена необхідність встановлення контрольованого обігу психотропних речовин на рівні з наркотичними засобами [8]. Конвенція про психотропні речовини 1971 року [9] стала першим самостійним законодавчим актом міжнародно-правового характеру, яким було визначено поняття психотропних речовин та необхідність їх контрольованого обігу. Прийнята вона була на основі Протоколу, яким поширювався контроль на лікарські засоби, що не охоплювалися Єдиною конвенцією про наркотичні засоби 1961 року (1971 рік). Конвенція 1971 року передбачала заходи контролю за обігом психотропних речовин, заходи кримінального покарання та методи поводження з їх споживачами. Фактично дана конвенція містила положення, схожі з Єдиною конвенцією 1961 року, з тією лише відмінністю, що наркотичні засоби були замінені на психотропні речовини. У зазначеній конвенції було враховано й види психотропів. Розподіл психотропів на групи галюциногенів, стимуляторів та заспокійливих було здійснено за різними критеріями: а) їх призначенням; б) сферою використання (психіатрія, терапія, неврологія); в) хімічним складом; г) фармакологічною дією; д) терапевтичною корисністю; е) кількістю психоактивної речовини (концентрацією); є) ступенем та видом залежності, що викликає їх вживання. Усе це було здійснено для того, щоб встановити різні режими обігу для психотропних речовин та формами 
контролю за їх обігом. У конвенції було передбачено, що контроль на міжнародному рівні за психотропними речовинами повинна буде здійснювати Всесвітня організація охорони здоров'я (ВОО3) [9].

У напрямку організації співпраці держав-учасниць на міжнародному рівні Конвенція 1988 року [10] передбачає створити максимально схожі, одноманітні правові заходи в національному законодавстві [11]. У якості найбільш ефективних заходів кримінально-правового впливу відносно наркозлочинщів Конвенції 1961 та 1971 року [8, 9] називають такі види покарань, як: позбавлення волі, штраф, конфіскація.

У 2003 році учасницями Конвенції 1988 року [10] були 149 країн світу, у тому числі, країни Євросоюзу, то в 2015 році - уже близько 170.

Крім розглянутих нами конвенщій, необхідно звернути увагу й на інші правові акти, що приймала ООН протягом останніх десятиліть з питань протидії наркозлочинності. Такими, наприклад, є низка протоколів про наркотичні засоби та питання взаємодії країн світу в боротьбі з незаконним виробництвом, обігом, торгівлею наркотиками та прекурсорами 1912, 1925, 1931, 1936, 1946, 1948, 1998 років [4]. Питанням боротьби з незаконним обігом наркотиків, психотропів та прекурсорів за останні 25 років присвячено доповіді секретарів ООН 1990, 1995, 2011, 2012, 2013, 2014 та 2015 років, лист 1998 року, програми 1999 та 2012 років, угода 2005 року, щорічні доповіді Міжнародного комітету по контролю над наркотиками (у тому числі за 2006, 2007, 2009, 2010, 2011, 2012, 2013, 2014, 2015 роки). Необхідно відзначити, що в документах ООН, іiі комісій та Секретаря використовується термін «боротьба» 3 незаконним обігом, торгівлею, виробництвом тощо, а не протидія, як у національному антинаркотичному законодавстві. Причиною цього, на наш погляд, є підміна понять, що має місце в українському кримінальному законодавстві, про яку детально говорять вітчизняні автори С. А. Шалгунова та О.О. Шевцова [12]. На це звертають увагу й інші науковці, зокрема В. О. Негодченко, В. В. Шендрик, І. О. Крєпаков [13, 14]. Тож для поліпшення антинаркотичного законодавства України (із врахуванням досвіду європейських країн у сфері боротьби 3 наркозлочинністю) слід також посилити роль громадськості в цьому процесі $[15,18]$.

Згідно 3 чинним законодавством України кримінальна відповідальність за наркозлочини передбачена в розділі XIII Особливої частини «Злочини у сфері обігу наркотичних засобів, психотропних речовин, їх аналогів або прекурсорів та інші злочини проти здоров'я населення» [16], у якому 16 статей із 24-х стосуються діянь, пов' язаних саме 3 наркозлочинами. Кримінально-правові заборони, встановлені в чинному KK України, спрямовані, перш за все, на запобігання наркозлочинів під страхом кримінального покарання, i, зважаючи на суворість санкцій, мають найбільшу силу кримінальної репресії в порівнянні 3 іншими діяннями, пов'язаними 3 незаконним обігом наркотичних засобів, психотропних речовин, їх аналогів та прекурсорів. Встановлення таких заборон має як загально-превентивну, так й індивідуально-превентивну функцію, оскільки стосується як всього населення, так і тих громадян, які притягуються до кримінальної відповідальності за вчинення окремих 
злочинів.

Так само, як і відносно інших видів злочинів, при вчиненні наркозлочину в залежності від ступеня його тяжкості законодавець передбачає можливість звільнення особи від кримінальної відповідальності на загальних підставах (ст. 44 КК України) та за спеціальних умов, визначених у законі (ст. 307 ч. 4, ст. 309 ч. 4, ст. 311 ч. 4 КК України). Однак звільнення від кримінальної відповідальності особи, яка вчинила злочин у стані сп'яніння (алкогольного чи наркотичного) законом не передбачено. Крім того, вчинення злочину в такому стані визнається в якості обтяжуючої покарання обставини згідно 3 положеннями ст. 67 ч. 1 п. 13 КК України. Винятки складають лише ті випадки, коли наркозалежна особа або особа, яка вчинила злочин у стані наркотичного сп'яніння, перебували в стані патологічного сп'яніння, i були визнані неосудними на момент вчинення злочину. Вітчизняним кримінальним законом передбачено й положення, що такій особі на розсуд суду може бути призначено примусове лікування від наркотичної залежності (ст. 96 ч. 1 КК України), але це не є обов'язковим правилом для всіх наркозалежних осіб. Умовою призначення примусового лікування $є$ наявність хвороби, що становить небезпеку для здоров'я інших осіб.

На наш погляд, таке положення закону є відносно гуманним щодо наркозалежної особи або тієї, яка епізодично вживає наркотичні засоби чи психотропні речовини і вчиняє злочини. Але 3 іншого, - це не гуманно відносно інших, законослухняних членів суспільства, які потребують створення безпечних умов життя, у тому числі убезпечення їх від вчинення злочинів з боку наркозалежних осіб. Тому ми вважаємо, що правило призначення примусового лікування повинно бути обов' язковим відносно всіх категорій осіб, які вчинили злочини в стані наркотичного сп'яніння, а саме: тих, хто має стійку хворобливу залежність від вживання наркотиків та психотропів, і тих, хто вживає їх епізодично або спробував наркотик уперше, і це стало причиною чи приводом для вчинення злочину. Диференціація таких осіб може проводитися в межах лікувального закладу, який визначатиме термін та обсяг примусового лікування, його інтенсивність та вибір місця лікування (лікувальний заклад відкритого чи закритого типу або амбулаторне лікування). Таким чином, ми вважаємо, можна обмежити можливість необгрунтованого застосування судами заходів примусового лікування та порушень медичних настанов у його здійсненні. Тим більше, що рішення про припинення примусового лікування приймається лікарями-наркологами та психіатрами колегіально, а не одноосібно.

Головним правилом чинного кримінального закону є домінування превенції над заходами кримінальної репресії (ст. 1 КК України, ст. 1 КВК України). На наш погляд, це є проявом принципу гуманного ставлення до наркозалежної особи, яка вчинила будь-який злочин, у тому числі і наркозлочин. Головною метою чинного кримінальновиконавчого закону, так само, як і кримінального, визначено 
запобігання нових злочинів особами, засудженими за вчинення злочинів, а також вчинення злочинів іншими особами, які іще не притягувалися до кримінальної відповідальності, а лише задумують чи готують вчинення злочинів (ст. 1 КВК України, ст. 1 КК України).

Для порівняння Кримінальний кодекс Республіки Білорусь у Главі 29 «Злочини проти здоров'я населення» містить наступні діяння: розкрадання наркотичних засобів, психотропних речовин або їх прекурсорів або аналогів (ст. 327), незаконний обіг наркотичних засобів, психотропних речовин, їх прекурсорів та аналогів (328), незаконне переміщення через митний кордон Свразійського Економічного Союзу або державний кордон Республіки Білорусь наркотичних засобів, психотропних речовин або їх прекурсорів або аналогів (328/1), споживання наркотичних засобів, психотропних речовин або їх аналогів у громадському місці або поява в громадському місці чи знаходження на роботі в стані, викликаному вживанням наркотичних засобів, психотропних речовин, їх аналогів, токсичних або інших одурманюючих речовин (328/2), посів або вирощування заборонених до обробітку рослин або грибів, що містять наркотичні засоби або психотропні речовини (329), порушення правил поводження 3 наркотичними засобами, психотропними речовинами, їх прекурсорами й аналогами (330), схиляння до вживання наркотичних засобів, психотропних речовин або їх аналогів (331), надання приміщень, організація або утримання місць розпусти для виготовлення, переробки та (або) споживання наркотичних засобів, психотропних речовин, їх аналогів або інших одурманюючих речовин (332) [17].

Пенітенціарний кодекс Естонії у Главі 12 «Винні діяння проти здоров'я населення», до складу якої входить Розділ 1 «Винні діяння, пов' язані з наркотиками», нараховує у своєму складі наступні суспільно небезпечні діяння: незаконний обіг наркотичних засобів і психотропних речовин у невеликих розмірах (ст. 183), незаконний обіг наркотичних засобів і психотропних речовин у великому розмірі (ст. 184), передача наркотичних засобів і психотропних речовин особам, які не досягли вісімнадцятирічного віку (ст. 185), схиляння до незаконного вживання наркотичних засобів і психотропних речовин (ст. 186), схиляння неповнолітнього до незаконного вживання наркотичних засобів, психотропних речовин або інших одурманюючих речовин (ст. 187), незаконне вирощування опійного маку, конопель і кокаїнових кущів (ст. 188), приготування до розповсюдження наркотичних засобів і психотропних речовин (ст. 189), порушення вимог до обороту й обліку наркотичних засобів або психотропних речовин та їх прекурсорів та звітності за ними (ст. 190) [19].

Окремої уваги заслуговують положення Пенітенціарного кодексу Естонії, визначені ст. 191, щодо конфіскації судом речовини або предметів, що є безпосередніми об'єктами здійснення винних діянь, або предметів, використаних при приготуванні до винних діянь.

Детально врегульовані термінологічні питання у сфері 
наркозлочинності в Кримінальному кодексі Республіки Молдова (далі - КК РМ). Відповідно до ст. $134^{1}$ КK РМ під наркотиками розуміються встановлені Урядом рослини й наркотичні (одурманюючі) або психотропні речовини чи суміш таких рослин та речовин (п. 1); під наркотичними (одурманюючими) речовинами речовини, внесені в додатки до Єдиної конвенщіїООН про наркотичні засоби 1961 року з поправками за Протоколом 1972 року і передбачені нормативними актами Уряду (п. 2); під психотропними речовинами - такі, що, вміщені в додатки до Конвенщії про психотропні речовини 1971 року і передбачені нормативними актами Уряду (п. 3); під прекурсором - речовина природного або синтетичного походження, що використовується в якості сировини для виробництва наркотичних і психотропних речовин (п. 4); під етноботанічними засобами -суміш порошків i/або рослин чи суміш трав і різних частин рослин, які обприскані хімічними речовинами, що викликають зміни з фізіологічними, психічними, галюциногенні і / або психоактивними ефектами (п. 5); під аналогом наркотичного або психотропної речовини - будь-яка речовина або комбінація речовин природного або синтетичного походження в будь-якому фізичному стані чи будьякий продукт, рослина, гриб або їх частини, які мають здатність викликати психоактивні ефекти, і які, незалежно від змісту, найменування, способу прийому, уявлення або рекламування, є або можуть бути використані замість наркотичної речовини, наркотичного, психотропного препарату або препарату, який володіє психотропним ефектом, а також замість рослини або речовини, що підлягає національному та/або міжнародного контролю (п. 6) [20]. Враховуючи положення п. 9 згаданої норми, під оборотом наркотиків, прекурсорів, етноботанічних засобів й аналогів таких розуміється будь-яка операція, як то: експериментування, розробка, виробництво (виготовлення), приготування, вирощування, екстракція, переробка, перетворення, володіння, складування, зберігання, постачання, відпуск, розподіл, відправка, перевезення, придбання (купівля), реалізація, знищення, імпорт, експорт, використання, їх просування та інші суміжні дії. Самі ж кримінально карані діяння містяться у Главі VIII «Злочини проти суспільного здоров'я та суспільного життя», якими законодавець визначив наступні: незаконний обіг наркотиків, етноботанічних засобів або їх аналогів не з метою відчуження (ст. 217), незаконний обіг наркотиків, етноботанічних засобів або їх аналогів 3 метою відчуження (ст. 2171), незаконний обіг прекурсорів 3 метою виробнищтва або переробки наркотиків, етноботанічних засобів або їх аналогів (ст. 2172), незаконний обіг матеріалів та обладнання для виробництва або переробки наркотиків, етноботанічних засобів або їх аналогів (ст. 2173), розкрадання або вимагання наркотиків або етноботанічних засобів (ст. 2174), публічне незаконне вживання або організація місць незаконного вживання наркотиків, етноботанічних засобів або їх аналогів (ст. 2175), незаконне навмисне введення в організм іншої особи проти їі волі наркотиків, етноботанічних засобів або їх аналогів (ст. 2176), незаконне призначення або порушення правил обігу наркотиків (ст. 218), організація або утримання притонів для вживання наркотиків або етноботанічних засобів (ст. 219).

Висновки. Отже, ми розглянули питання еволюції міжнародного антинаркотичного законодавства та встановлення правових, у тому числі 
кримінально-правових, заборон на вільний обіг психотропних речовин. Прийняті $\mathrm{OOH}$ міжнародно-правові акти дозволили певним чином уніфікувати підходи законодавців різних краӥн у сфері боротьби з наркобізнесом та наркоманією та визначити едині для всіх шляхи й підходи в обмеженні незаконного обігу наркотичних засобів та психотропних речовин, а пізніше і їх аналогів, а також установити міжнародний контроль за їх легальним обігом. Конвенції, протоколи та доповнення до них стали тими правовими актами, які створювали базу для національного законодавства в питаннях правової регламентації кримінальноправових заборон та боротьби з незаконним обігом наркотичних засобів $\mathrm{i}$ психотропних речовин. Це суттєво полегшувало роботу законодавчих органів країн, які приєдналися до цих конвенцій, і дозволило визначати пріоритетні напрями протидії наркозлочинності в Україні. Антинаркотична політика безпосередньо взаємопов'язана в цілому зі станом злочинності, і наркозлочинності в тому числі, оскільки є однією із складових загальної безпеки життя українського суспільства. Аналіз положень кримінального законодавства деяких європейських країн вказує ще й на те, що кримінальна відповідальність за наркотичні злочини із певними особливостями, притаманна кожній із перерахованих краӥн.

\section{Використані джерела:}

1. Симакова И.Н. Проблемы квалификации незаконных действий с психотропными веществами: Теория и практика. Екатеринбург: Уральская гос. юрид. академия, 2003. 20 c.

2. Авакян Р.О. Наркомания и методы борьбы с нею. Спец. ред. Г. М. Воскресенский. Ереван: Айастан, 1990. 323 с.

3. Резолюция Шанхайской опиумной комиссии 1909 года. / [Електронний ресурс: Федеральная служба Российской Федерации по контролю за оборотом наркотиков. Аппарат Государственного антинаркотического комитета Управления по Уральскому федеральному округу]. Режим доступу: http://fskn.1gb.ru. Дата звернення: 25.05.2019.

4. Конвенція про наркотики 1912 року (м. Гаага) / Протокол о внесении изменений в Соглашения, Конвенции и Протоколы о наркотиках, заключенные в Гааге 23 января 1912 года, в Женеве 11 февраля 1925 года, 19 февраля 1925 года и 13 июля 1931 года, в Бангкоке 27 ноября 1931 года и в Женеве 26 июня 1936 года, 1946 года, 1948 года, 1998 года. / [Електронний ресурс]. Режим доступу: http:// docs.cntd.ru/document/1901505. Дата звернення: 01.06.2019.

5. Сборник действующих договоров, соглашений и конвенций, заключённых с иностранными государствами. М.: Народный комиссариат иностранных дел, 1938. Вып. IX. С. 472-479.

6. Женевская Международная Конвенция от 26 июня 1936 года по борьбе с нелегальной торговлей сильнодействующими средствами. Сборник действующих договоров, соглашений и конвенций, заключённых с иностранными государствами. М.: Народный комиссариат иностранных дел, 1938. Вып. IX. С. 450496; Вып. ХІІІ. № 551. С. 480-487.

7. Сборник действующих договоров, соглашений и конвенций, заключённых СССР с иностранными государствами. М.: Международные отношения, 1970. Вып. XXIII. C. 105-136. 
8. Про наркотичні засоби: Єдина Конвенція Організації Об'єднаних Націй 1961 року. [Електронний ресурс: Офіційний сайт Верховної Ради України]. Режим доступу: http:/ / rada.gov.ua. Дата звернення: 12.05.2019.

9. Про психотропні речовини: Конвенція Організації Об'єднаних націй 1971 року. [Електронний ресурс: Офіційний сайт Верховної Ради України]. Режим доступу: http:/ / rada.gov.ua. Дата звернення: 12.05.2019.

10. Про боротьбу проти незаконного обігу наркотичних засобів та психотропних речовин: Конвенція Організації Об'єднаних Націй 1988 року. [Електронний ресурс: Офіційний сайт Верховної Ради України]. Режим доступу: rada.gov.ua. Дата звернення: 12.05.2019.

11. Перелік наркотичних засобів, психотропних речовин і прекурсорів : Постанова Кабінету Міністрів України від 06 травня 2000 року № 770. [Електронний ресурс: Офіційний сайт Верховної Ради України]. Режим доступу : http:/ / rada.gov.ua. Дата звернення: 12.05.2019.

12. Шевцова О. О., Шалгунова С. А. Сучасні кримінологічні проблеми обліку злочинів. Сучасні проблеми розвитку державності та напрями їх вирішення через призму правотворчої діяльності: матеріали міжнародної науково-практичної конференції, (м. Харків, 20-21 червня 2014 року). Харків: ГО «Асоціація аспірантівюристів», 2014. С. 79-81.

13. Негодченко В. О. Діяльність органів внутрішніх справ щодо попередження злочинів в сучасних умовах : автореф. на здобуття наукового ступеня докт. юрид. X., 2003. 20 c.

14. Шендрик В. В., Крєпаков I. О. Аналіз співвідношення понять «профілактика», «попередження», «припинення» та «запобігання злочинів». Форум права. 2011. № 1. С. 1129-1139. [Електронний ресурс]. Режим доступу : http:/ / www.nbul.gov.ua/e-journals/FP-2011-1/11

15. Нестерович В. Ф. Вплив громадськості на прийняття нормативно-правових актів: проблеми конституційної теорії та практики: Монографія. Луганськ: РВВ ЛДУВС ім. Е. О. Дідоренка, 2014. 736 с.

16. Кримінальний кодекс України (із зм. та доп. станом на 5 вересня 2014 р.). Х.: Одіссей, 2014. 232 с.

17. Уголовный кодекс Республики Беларусь от 9 июля 1999 г. (с изм. сост. на 5 июля 2016 г.)[Електронний ресурс]. Режимдоступу: http:/ /www.pravo.by/documen t/?guid=3871\&p0=Hk9900275. Дата звернення: 12.10 .2018 p.

18. Нестерович В. Ф. Конституционно-правовое регулирование консультативно-совещательных органов в европейских государствах. ЮристьПравоведъ. 2013. № 3. С. 31-35.

19. Пенитенциарный кодекс Эстонской Республики от 6 июня 2001 г. (с изм. сост. на 15 июля 2018 г.) [Електронний ресурс]. Режим доступу: https://v1.juristaitab.ee/sites/www.juristaitab.ee/files/elfinder/ruseadused/ПЕНИТ ЕНЦИАРНЫЙ\%20КОДЕКС\%. Дата звернення: 12.10 .2018 р.)

20. Уголовный кодекс Республики Молдова от 18 апреля 2002 г. (с изм. сост. на 24 мая 2018 г.) [Електронний ресурс]. Режим доступу: http:/ / lex.justice.md/ru/331268/. Дата звернення: 12.10.2018 р.)

\section{References}

1. Simakova I.N. (2003) Problemy kvalifikacii nezakonnyh dejstvij s psihotropnymi veshestvami: Teoriya i praktika [Problems of qualification of illegal actions with 
psychotropic substances: Theory and practice]. Ekaterinburg: Uralskaya gos. yurid. akademiya, 20 s. [in Russian]

2. Avakyan R.O. (1990) Narkomaniya i metody borby s neyu [Addiction and methods of dealing with it]. Spec. red. G.M. Voskresenskij. Erevan: Ajastan, 323 s. [in Armenia]

3. Rezolyuciya Shanhajskoj opiumnoj komissii 1909 goda (1909) / [Elektronnij resurs: Federalnaya sluzhba Rossijskoj Federacii po kontrolyu za oborotom narkotikov. Apparat Gosudarstvennogo antinarkoticheskogo komiteta Upravleniya po Uralskomu federalnomu okrugu]. Rezhim dostupu: http:/ / fskn.1gb.ru. Data zvernennya: 25.05.2019.

4. Konvenciya pro narkotiki 1912 roku (m. Gaaga) / Protokol o vnesenii izmenenij v Soglasheniya, Konvencii i Protokoly o narkotikah, zaklyuchennye v Gaage 23 yanvarya 1912 goda, v Zheneve 11 fevralya 1925 goda, 19 fevralya 1925 goda i 13 iyulya 1931 goda, v Bangkoke 27 noyabrya 1931 goda i v Zheneve 26 iyunya 1936 goda,1946 goda,1948 goda, 1998 goda. /[Elektronnij resurs]. Rezhimdostupu: http:/ /docs.cntd.ru/document/1901505. Data zvernennya: 01.06.2019 [in Netherlands]

5.Sbornik dejstvuyushih dogovorov, soglashenij i konvencij, zaklyuchyonnyh s inostrannymi gosudarstvami (1938). M.: Narodnyj komissariat inostrannyh del. Vyp. IX. S. 472-479 [in Russian]

6. Zhenevskaya Mezhdunarodnaya Konvenciya ot 26 iyunya 1936 goda po borbe s nelegalnoj torgovlej silnodejstvuyushimi sredstvami. Sbornik dejstvuyushih dogovorov, soglashenij i konvencij, zaklyuchyonnyh s inostrannymi gosudarstvami. M.: Narodnyj komissariat inostrannyh del, 1938. Vyp. IX. S. 450-496; Vyp. XIII. № 551. S. 480-487.

7. Sbornik dejstvuyushih dogovorov, soglashenij i konvencij, zaklyuchyonnyh SSSR S inostrannymi gosudarstvami (1970). M.: Mezhdunarodnye otnosheniya. Vyp. XXIII. S. 105-136 [in Russian]

8. Pro narkotichni zasobi: Yedina Konvenciya Organizaciyi Ob'yednanih Nacij 1961 roku. [Elektronnij resurs: Oficijnij sajt Verhovnoyi Radi Ukrayini]. Rezhim dostupu: http:/ / rada.gov.ua. Data zvernennya: 12.05.2019.

9. Pro psihotropni rechovini: Konvenciya Organizaciyi Ob'yednanih nacij 1971 roku. [Elektronnij resurs: Oficijnij sajt Verhovnoyi Radi Ukrayini]. Rezhim dostupu: http:/ / rada.gov.ua. Data zvernennya: 12.05.2019.

10. Pro borotbu proti nezakonnogo obigu narkotichnih zasobiv ta psihotropnih rechovin: Konvenciya Organizaciyi Ob'yednanih Nacij 1988 roku. [Elektronnij resurs: Oficijnij sajt Verhovnoyi Radi Ukrayini]. Rezhim dostupu: rada.gov.ua. Data zvernennya:12.05.2019.

11. Perelik narkotichnih zasobiv, psihotropnih rechovin i prekursoriv : Postanova Kabinetu Ministriv Ukrayini vid 06 travnya 2000 roku № 770. [Elektronnij resurs: Oficijnij sajt Verhovnoyi Radi Ukrayini]. Rezhim dostupu : http:/ / rada.gov.ua. Data zvernennya: 12.05.2019 [in Ukrainian]

12. Shevcova O.O., Shalgunova S.A. (2014) Suchasni kriminologichni problemi obliku zlochiniv. Suchasni problemi rozvitku derzhavnosti ta napryami yih virishennya cherez prizmu pravotvorchoyi diyalnosti: materiali mizhnarodnoyi naukovopraktichnoyi konferenciyi, (m. Harkiv, 20-21 chervnya 2014 roku). Harkiv: GO «Asociaciya aspirantiv-yuristiv», S. 79-81 [in Ukrainian]

13. Negodchenko V.O. (2003) Diyalnist organiv vnutrishnih sprav shodo poperedzhennya zlochiniv $\mathrm{v}$ suchasnih umovah : avtoref. na zdobuttya naukovogo stupenya dokt. yurid. H., 20 s. [in Ukrainian]

14. Shendrik V.V., Kryepakov I.O. (2011) Analiz spivvidnoshennya ponyat «profilaktika», «poperedzhennya», «pripinennya» ta «zapobigannya zlochiniv». Forum 
prava. № 1. P. 1129-1139. [Elektronnij resurs]. Rezhim dostupu : http://www.nbul.gov.ua/e-journals/FP-2011-1/11 [in Ukrainian].

15. Nesterovych V.F. (2014) Vplyv hromads' kosti na pryynyattya normatyvnopravovykh aktiv: problemy konstytutsiynoyi teoriyi ta praktyky: Monohrafiya [Public Impact on the Adoption of Regulations: Problems of Constitutional Theory and Practice: Monograph]. Luhans' k: RVV LDUVS im. E. O. Didorenka [in Ukrainian].

16. Kriminalnij kodeks Ukrayini (iz zm. ta dop. stanom na 5 veresnya 2014 r.). H.: Odissej, 2014. 232 s. [in Ukrainian]

17. Ugolovnyj kodeks Respubliki Belarus ot 9 iyulya 1999 g. (s izm. sost. na 5 iyulya 2016 g.) [Elektronnij resurs]. Rezhim dostupu: http:/ / www.pravo.by/docume nt/ ?guid=3871\&p0=Hk9900275. Data zvernennya: 12.10.2018. [in Belarus]

18. Nesterovych V.F. (2013) Konstitutsionno-pravovoye regulirovaniye konsul'tativno-soveshchatel'nykh organov $\mathrm{v}$ yevropeyskikh gosudarstvakh [Constitutional and legal regulation of advisory bodies in European states]. Yurist-Pravoved. № 3. S. 31-35 [in Ukrainian]

19. Penitenciarnyj kodeks Estonskoj Respubliki ot 6 iyunya 2001 g. (s izm. sost.na 15 iyulya 2018 g.)[Elektronnijresurs].Rezhimdostupu: https://v1.juristai tab.ee/sites/www.juristaitab.ee/files/elfinder/ruseadused/PENITENCIARNY J\%20KODEKS\%. Data zvernennya: 12.10 .2018 r.) [in Estonia]

20. Ugolovnyj kodeks Respubliki Moldova ot 18 aprelya 2002 g. (s izm. sost. na 24 maya 2018 g.) [Elektronnij resurs]. Rezhim dostupu: http://lex.justice.md/ru/331268/. Data zvernennya: 12.10.2018 r.) [in Moldova]

Стаття надіӥшла до редколегї 07.05.2019

Шалгунова С. А., кандидат юридических наук, доцент, заведующая кафедрой уголовно-правовых дисциплин Днепропетровкого государственного университета внутренних дел (г. Днепр, Украина)

Скок А. С., кандидат юридических наук, доцент кафедры уголовно-правовых дисциплин Днепропетровкого государственного университета внутренних дел (г. Днепр, Украина)

\section{ФОРМИРОВАНИЕ АНТИНАРКОТИЧЕСКОГО ЗАКОНОДАТЕЛЬСТВА УКРАИНЫ С УЧЕТОМ ОПЫТА ЕВРОПЕЙСКИХ СТРАН В СФЕРЕ БОРЬБЫ С НАРКОПРЕСТУПНОСТЬЮ}

Статья посвящена процессам формирования антинаркотического законодательства Украины с учетом опыта европейских стран в сфере борьбы с наркопреступностью. В работе изучены международные документы, которые определяют принципы, методы и основные направления государственной антинаркотической политики. 
Рассмотрено уголовное законодательство об особенностях установления уголовной ответственности за наркотические преступления. Выявлены проблемы подмены понятий в отечественном уголовном законодательстве и установлено, что национальная антинаркотическая политика основывается на международных правовых актах, принятых преимущественно ООН.

Ключевые слова: наркотики, наркомания, наркобизнес, наркопреступность, уголовная ответственность, антинаркотическая политика.

Shalgunova S.,

candidate of law, associate professor, head of the department of criminal law disciplines of the Dnipropetrovsk state university of internal affairs

(Dnepro, Ukraine)

Skok A.,

candidate of law, associate professor department of criminal law disciplines, Dnipropetrovsk state university of internal affairs

(Dnepro, Ukraine)

\section{FORMATION ANTIDRUG LEGISLATION OF UKRAINE, TAKING INTO THE ACCOUNT OF THE EXPERIENCE OF EUROPEAN COUNTRIES IN THE FIGHT AGAINST DRUG CRIME}

The article is devoted to the processes of formation of anti-narcotic legislation of Ukraine taking into account the experience of European countries in the field of combating drug crime. The article examines international documents that determine the principles, methods and main directions of state anti-narcotic policy. The criminal legislation on the peculiarities of establishing criminal liability for narcotic crimes is considered. Problems of substitution of concepts in domestic criminal law are revealed. It has been established that national anti-narcotic policies are based on international legal acts adopted mainly by the UN. The positive influence of international regulatory documents on the problems of drug business and drug addiction not only within the individual country but also in the world is substantiated. The article deals with the evolution of international anti-narcotic legislation and the establishment of legal, including criminal, prohibitions on the free circulation of psychotropic substances. Attention is paid to the analysis of international legal acts. The issue of criminal liability for drug crimes in Ukraine is investigated. The criminal legal prohibitions established in the current Criminal Code of Ukraine are examined, and how they contribute to the prevention of criminal offenses under the fear of criminal punishment. The main positive aspect of antinarcotics conventions was found to be that they provided for and established international legal measures on drug trafficking and mutual assistance and cooperation between different states in this field. The article determines that antinarcotic policy is directly interrelated with the whole state of crime, including drug crime, as it is one of the components of the overall security of life of Ukrainian society. 
Criminal liability for narcotic offenses, with specific features, is inherent in each of the countries concerned.

Key words: drugs, drug addiction, drug business, drug crime, criminal liability, anti-drug policy. 